\title{
COMPLEMENT-FIXATION IN WHOOPING COUGH *
}

WALTER WINHOLT

(From the Memorial Instisute for Infectious Diseases, Chicago)

\section{INTRODUCTION}

Since Bordet and Gengou ${ }^{1}$ described the bacillus of pertussis in 1906 as the specific cause of whooping-cough, a number of investigators have studied the organism with respect to complement-fixation. Bordet and Gengou claim that this bacillus is the cause of whoopingcough, because it is found in overwhelming numbers during the early course of the disease, and because it gives complement-fixation with the serum of pertussis patients, this reaction not occurring with any other organism associated with the disease. However, according to some writers, there are several points which are not clearly demonstrated. In the first place, it is said that we lack sufficient evidence that this organism is present in every case of pertussis. The bacillus usually can be isolated in the early stages of pertussis, but after the second week it is not present in the sputum in sufficiently large numbers to be readily isolated. The influenza bacillus, on the other hand, can be isolated as early in whooping-cough as the Bordet-Gengou bacillus, and is present for a longer time. Secondly, complement-fixation with the serum of patients is said not to be as clear cut as it seems to be with the serum of animals which have been injected with the bacillus of pertussis. Finally, the results obtained with specific vaccines in treatment and prevention have not been altogether satisfactory. Thus Hartshorn and Moeller, ${ }^{2}$ in reviewing the literature on the use of pertussis vaccines, conclude that its prophylactic value is still undetermined.

\section{THE BACILLUS PERTUSSIS}

The bacillus pertussis has been carefully described by the discoverers and numerous investigators have confirmed their observations. It is a small, short, ovoid, non-motile bacillus, which does not form spores, and which does not have a capsule. It is said to be slightly larger than

* Received for publication March 12, 1915.

Aided by a grant from The Fenger Memorial Furd.

1. Ann. de l'Inst. Pasteur, 1906, 20, p. 731.
2. Arch. Pediat., 1914, 31, p. 580. 
the influenza bacillus. It stains well with methylene blue, dilute carbolfuchsin, and carbol-gentian-violet, the poles being frequently more deeply stained than the center. Usually the bacilli are separate and single, but they may appear in pairs and in chains.

Bordet and Gengou use a glycerin potato blood agar medium, but the organism grows well on ascitic agar, potato blood agar, and in ordinary blood agar. There seems to be little choice in the bloodhuman, rabbit, goat, or pigeon blood being used by different workers with equally good results.

On the potato glycerin blood agar, the growth is barely visible in twenty-four hours. In forty-eight hours the colonies have a gray, glistening appearance. The growth increases in thickness rather than in size. At times the growth assumes a pale blue color. The organism does not blacken the medium. On blood agar the growth is thin, and somewhat slow. The organism does not grow on plain agar, in litmus, milk, or broth. A few drops of blood in the broth make a good medium. The broth cultures containing a few drops of blood grow best when the tubes are kept in a slanting position, because the organism is such a strict aerobe. It is killed when heated to $56 \mathrm{C}$. for thirty minutes.

Morphologically, the influenza bacillus resembles the bacillus pertussis, the former being regarded as slightly smaller. Like the bacillus pertussis it is gram-negative, does not form spores, and is aerobic. It frequently stains more deeply at the ends than in the center. It requires hemoglobin for growth. On potato glycerin blood agar, the growth, after the first generation, is not as vigorous as the growth of the bacillus pertussis. When the organism is suspended in water, it gives an emulsion with a tendency to spontaneous agglutination, so that in drying on the slide the bacilli are frequently clumped in small masses. In preparations of whooping-cough bacillus, the organisms remain separated. The influenza bacillus frequently darkens the color of blood media, and this Bordet and Gengou ${ }^{3}$ regard as distinctive. On ascitic agar the whooping-cough bacillus grows slowly, as a white streak, while the influenza bacillus grows only very slightly, and not as well as the bacillus pertussis.

The influenza bacillus can be differentiated from the bacillus pertussis also by agglutination and complement-fixation. The serum of rabbits injected with the Bordet-Gengou bacillus, agglutinates the

3. Ann. de 1'Inst. Pasteur, 1907, 22, p. 720. 
organism in dilutions of $1-800$ or higher, but has no effect on the influenza bacillus. The serum of rabbits injected with the influenza bacillus, agglutinates this organism in dilutions of $1-500$ or so, and has no effect on the pertussis organism.

Moreover, positive complement-fixation is obtained by using the bacillus pertussis as antigen with the serum of rabbits injected with the organism, while negative results are obtained when the influenza bacillus is used as antigen with such serum. When the serum of rabbits injected with influenza bacilli is used, positive complementfixation is obtained with the influenza bacillus as antigen; negative results with the bacillus of pertussis.

\section{COMPLEMENT-FIXATION IN WHOOPING-COUGH}

The work on complement-fixation with the bacillus of pertussis has brought varied results, perhaps in part due to the different methods used to prepare the antigen.

Bordet and Gengou used suspensions in salt solution of growths on solid media. Wollstein used three forms of antigen: suspensions of the bacilli in salt solution; extracts of bacilli made by suspending the growths of three blood agar slants in 5 c.c. of salt solution and shaking for twenty-four hours in thermostat; and extracts of tissue obtained from patients dying from pertussis. Friedlander and Wagner ${ }^{5}$ used live bacteria and fresh serum, and considered this innovation of great importance. The different hemolytic systems employed may also have had some bearing on the failure to obtain identical results.

Bordet and Gengou obtained complement-fixation in all of their cases of pertussis. They used 0.1 c.c. to 0.3 c.c. of the human serum heated to $56 \mathrm{C}$, and 0.05 c.c. to 0.01 c.c. of fresh guinea-pig serum as complement. The amboceptor was the serum of rabbits previously injected with sheep corpuscles. The antigen was an emulsion of the bacillus of pertussis in salt solution, the growth being twenty-four hours old.

Arnheim ${ }^{3}$ obtained complement-fixation in six of twelve cases of pertussis. Wollstein examined the serum from nine patients with pertussis and in no instance did she obtain complement-fixation, using the three forms of antigen just mentioned in all cases. The quantities of complement and amboceptor were about the same as those used by Bordet and Gengou.

Gengou and Brunard ${ }^{7}$ describe three cases in which they determined the specific pertussis character of the infection by complement-fixation.

In 1911 Bordet and Gengou ${ }^{8}$ reported certain atypical cases diagnosed as pertussis by means of complement-fixation. A little later Bordet" concluded that the power to fix complement is not found early, and does not become marked until near the end of the disease.

4. Jour. Exper. Med., 1909, 11, p. 41.

5. Am. Jour. Dis. of Children, 1914,8, p. 134

6. Berl. klin. Wchnschr., 1908, 14, p. 1453.

7. Bull. Acad. de med. Belg., 1910,24, p. 329.

7. Centralbl. f. Bakteriol., I, O., 1911,58, p. 573

9. Ibid., 1912, 66, p. 275 . 
St. Bächer and Menschikoff ${ }^{10}$ report twenty-seven cases of pertussis in all stages in which attempts were made to obtain complement-fixation without success in a single case. Only after vaccines of pure cultures of the bacillus pertussis were given, did fixation occur. Their antigen was an emulsion of the bacillus of pertussis in salt solution, while 0.4 c.c. of a $1 / 10$ dilution of guineapig serum served as complement, and 0.5 c.c. of a $1 / 150$ dilution of serum of a rabbit previously injected with sheep corpuscles served as amboceptor.

Delcourt ${ }^{11}$ obtained complement-fixation in six cases of pertussis. Poleff ${ }^{12}$ gives a résumé of the results of five investigators. In five cases only was there complement-fixation and in thirty-one cases no fixation was obtained. $\mathrm{He}$, himself, reports ten cases in which he did not obtain fixation.

Hess ${ }^{13}$ tested ten cases and concluded "that results would seem to show that this reaction is present for some months after cessation of all symptoms."

Recently Anna Wessels Williams ${ }^{14}$ came to the conclusion that the test with serum of human beings is not as clear cut as it seems to be with serum of animals which have been injected with the bacillus of pertussis.

Renaux, ${ }^{15}$ using the bacillus pertussis for antigen, examined seventy-three sera for complement-fixation, thirty-two cases of which were known cases of pertussis. Of the cases of pertussis, he obtained complement-fixation in twenty-three. Of the nine negative cases, the serum had been obtained early during the disease, and three of these gave positive complement-fixation when the attack had lasted about four weeks. No further examination was made on the remaining six cases. His results seem to show that fixation appears about three or four weeks after the appearance of the whoop.

In eighteen cases of pertussis, Friedlander and Wagner ${ }^{16}$ obtained complement-fixation in each case. They used fresh serum of pertussis patients and living bacteria. The Noguchi hemolytic system was used throughout their work on account of the small quantity of serum necessary. They claim that the diagnosis of pertussis can be made with certainty in the catarrhal stage by means of complement-fixation. In a more recent article. Friedlander ${ }^{17}$ reports further results. He obtained fixation in thirteen of fourteen cases in the catarrhal stage before the characteristic whoop had appeared. In one case there was fixation three weeks before the first whoop.

This review shows that varied results have been obtained with complement-fixation in pertussis. The reaction is regarded as most pronounced late in the disease by Bordet and Gengou. Several investigators have found the reaction present after the cessation of all symptoms. Then, again, negative results have been obtained by Wollstein, St. Bächer, and Menschikoff, and others. Positive fixation has been obtained before the appearance of the whoop by Friedlander and Wagner.

10. Ibid., 61, p. 218.

11. Presse. med. Belg., 1912, 64, p. 19

12. Centralb1. f. Bakterial., 1 , G., 1913, 69, p. 23.

13. Jour. Am. Med. Ass11., 1914, 63, p. 1007.

14. Arch. Pediat., 1914, 31, p. 567 .

15. Centralbl. f. Bakteriol., f, O., 1914, 75, p. 197

16. Am. Jour. Dis. of Children, 1914, 8, p. 134.

17. Lancet-Clinic, 1915,113, p. 8 . 
AGGLUTINATION IN WHOOPING-COUGH

It has been found that the serum of children with pertussis agglutinates the bacillus of pertussis in varying concentrations.

Wollstein found that the serum of animals injected with the bacillus of pertussis agglutinates the organism in dilutions as high as 1-800, while no agglutination of the pertussis organism results with the serum of animals immunized with the influenza bacillus. The serum of animals immunized with the influenza bacillus agglutinates this bacillus in dilutions of $1-400$.

Bordet and Gengou found that agglutination took place on the addition of 0.002 c.c. of the serum of a horse immunized with the bacillus of pertussis to 1 c.c. of an emulsion of the pertussis organism. They further state that their horse serum agglutinated the strain that was used to immunize the animal less than it did another strain from a different case of pertussis.

Practically all agree that serum from patients suffering with pertussis show very inconstant agglutinative properties.

PERSONAL OBSERVATIONS

Due to the close resemblance between the bacillus pertussis and the influenza bacillus, I have made further experiments to study the relationship, if any exists, between these two organisms themselves on the one hand, and whooping-cough on the other, so far as determinable by means of complement-fixation and agglutination.

Bacteriological examinations were made on cases of whoopingcough in which the whoop was still present, and the bacillus pertussis was isolated. from three cases early in the disease. These strains corresponded to the description given by Bordet and Gengou of the bacillus pertussis. They corresponded also to the cultures from the American Museum in all ways, except that they were not so easily agglutinated. No agglutination or complement-fixation was obtained with these strains and the serum of rabbits immunized with the influenza bacillus. It may be mentioned that normal rabbit serum frequently agglutinates the pertussis organisms in dilution of $1-20$ or 1-30.

The culture of the bacillus pertussis obtained from the American Museum of Natural History, New York, answered in every way to the description given by Bordet and Gengou. After a number of subcultures had been made, this organism grew readily on blood agar. 
In all, fifty-one cases have been studied, twenty-two cases with a history of pertussis, and twenty-nine cases without any symptoms or recent history of pertussis.

Except for a few minor changes the test for complement-fixation has been made as described by Bordet and Gengou. The patient's blood was allowed to coagulate, the serum separated in the centrifuge and heated to $56 \mathrm{C}$. for twenty minutes. In the tests 0.01 c.c. to 0.04 c.c. of the undiluted serum was used. The amboceptor consisted of antisheep rabbit serum, diluted 1-10. The antigens consisted of seventy-two-hour growths of the bacillus of pertussis on potato glycerin blood agar and growths of the influenza bacillus on blood agar, the growths being washed off into normal salt solution and the suspensions heated to $56 \mathrm{C}$. for thirty minutes.

TABLE 1

Titration of Complement and Amboceptor

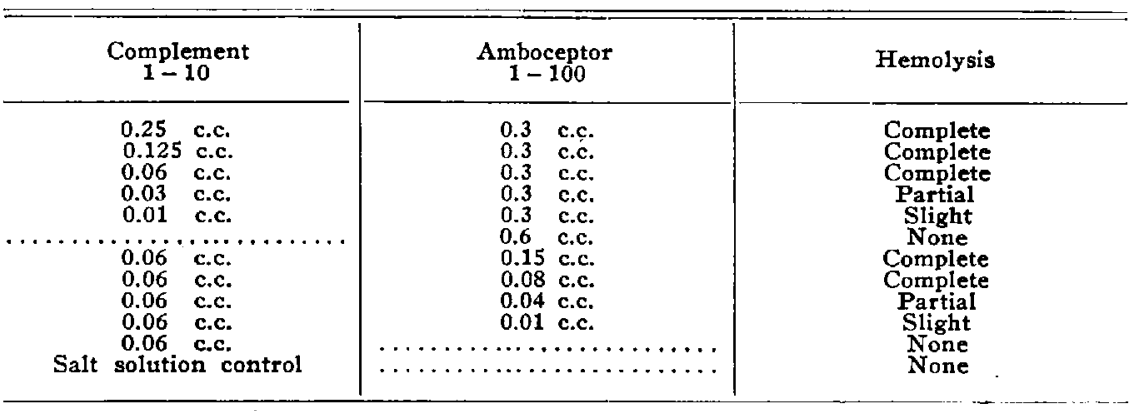

Each tube contains 0.35 percent sheep corpuscles. Total quantity in each tube $=1$ c.c.

Early in the work, the sera of rabbits previously injected with gradually increasing doses of bacillus pertussis were used for positive controls. The growths on two slants of potato glycerin blood agar were injected intraperitoneally. In three days a second injection was made with growth on these slants. Such injections were made every three days five times. At the end of this time strong fixation occurred. At intervals of four weeks, a single intraperitoneal injection was made, a strongly positive serum being thus maintained. In a similar way, rabbits were given intraperitoneal injections of the bacillus influenzae in order to get a good positive serum.

Complement and amboceptor were titrated in the usual way, as shown in Table 1. The method of titration of antigen is shown in Table 2. Various amounts of patients' serum were used in the fixation tests. 
TABLE 2

TITRATION OF ANTIGEN

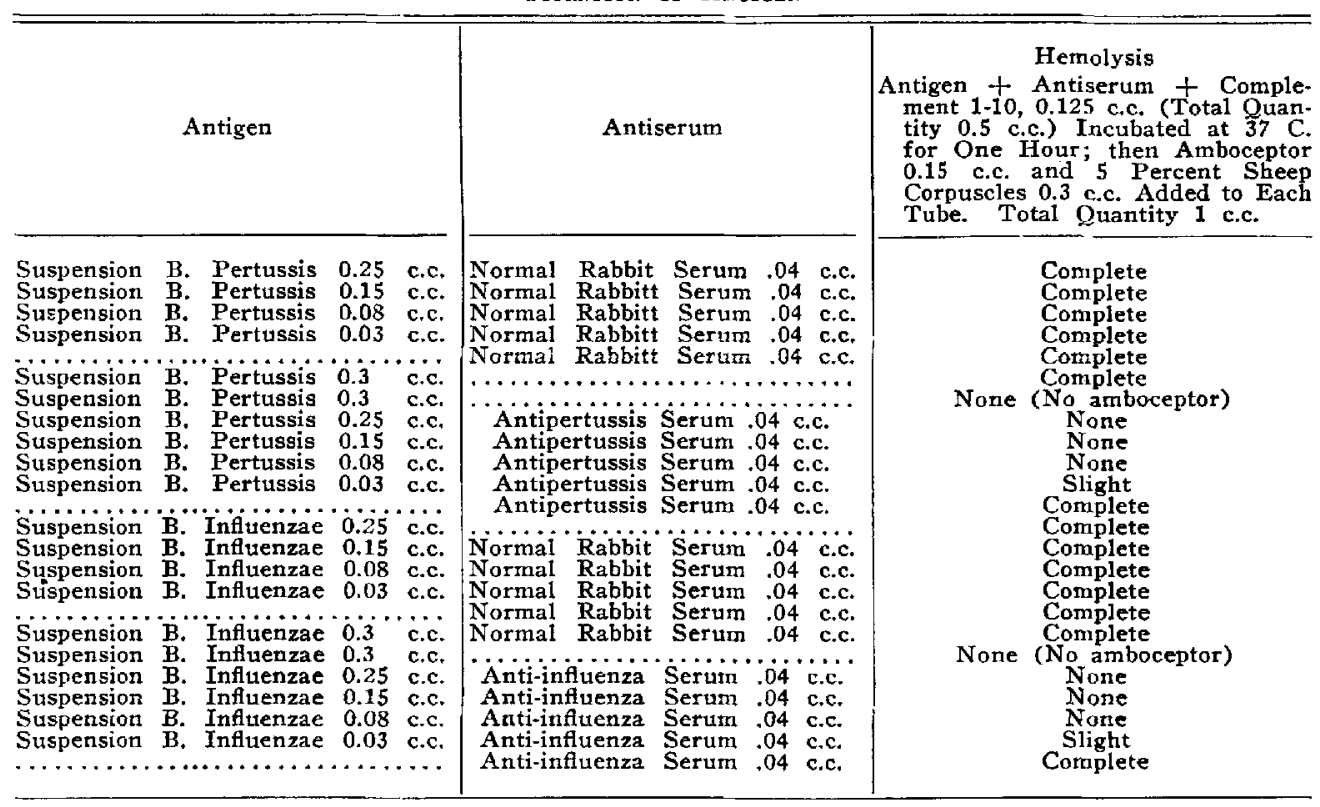

TABLE 3

Complement-Fixation Tests

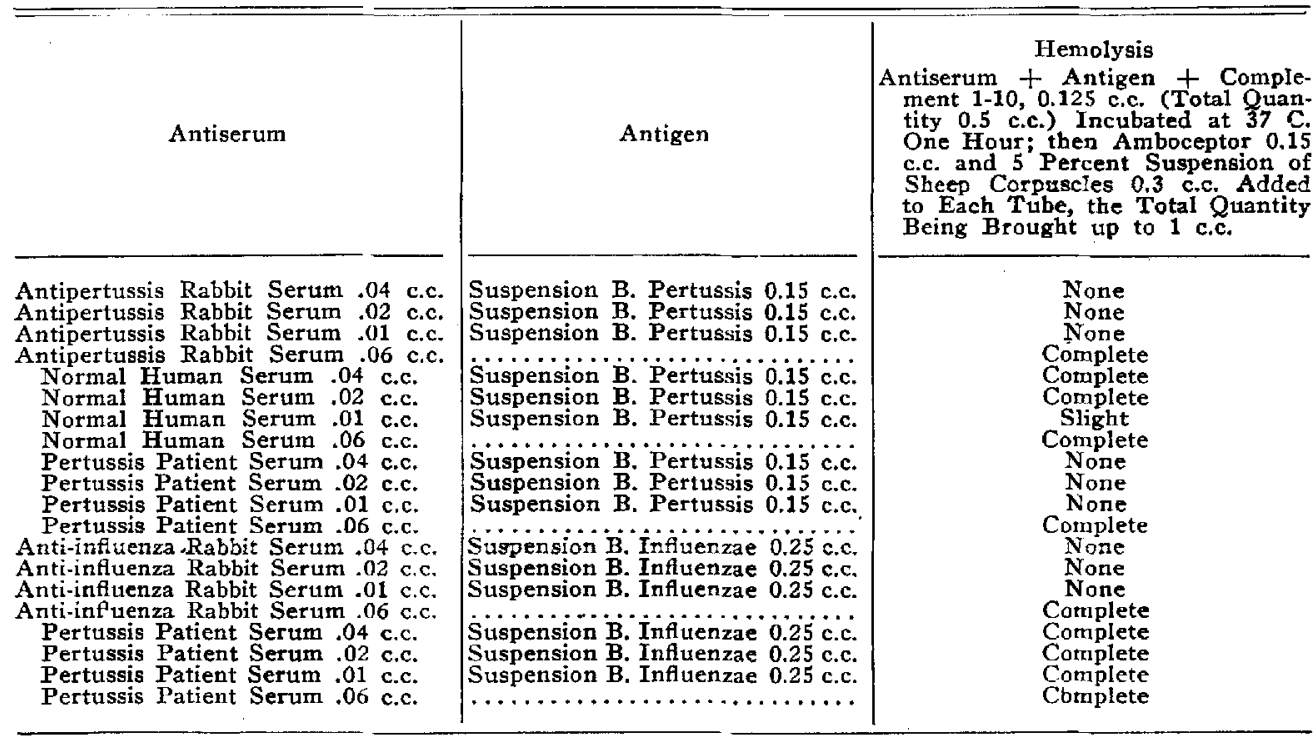


A full set of controls was made with every test. Tests for anticomplementary properties and for natural amboceptor were made always. By using the Bordet-Gengou bacillus and the influenza bacillus as antigens, complement-fixation tests were made in twenty-eight cases without any symptoms or history of pertussis. This series included normal persons, patients with measles, scarlet fever, chickenpox, and bronchitis. In no case was there any fixation of complement with either the pertussis organism or the influenza bacillus, the hemolysis being always complete. This series included three persons who had had pertussis two years, three years, and five years previously, but no fixation was observed.

TABLE 4

Complement-Fixation and Agglutination Tests with Bacillus Pertusis and Bacillus Influenza in WhoopingCovgh

\begin{tabular}{|c|c|c|c|c|c|c|}
\hline \multirow{2}{*}{ Number } & \multirow{2}{*}{ Age } & \multirow{2}{*}{$\begin{array}{c}\text { Duration of } \\
\text { Disease }\end{array}$} & \multicolumn{2}{|c|}{ Complement-Fixation } & \multicolumn{2}{|c|}{ Agglutination } \\
\hline & & & B. Pertussis & B. Influenzae & B. Pertussis & B. Influenzae \\
\hline $\begin{array}{r}1 \\
2 \\
3 \\
4 \\
5 \\
6 \\
7 \\
8 \\
9 \\
10 \\
11 \\
12 \\
13 \\
14 \\
15 \\
16 \\
17 \\
18 \\
19 \\
20 \\
21 \\
22\end{array}$ & $\begin{array}{r}17 \text { months } \\
5 \text { years } \\
4 \text { years } \\
4 \text { years } \\
7 \text { years } \\
6 \text { months } \\
2 \text { years } \\
3 \text { years } \\
6 \text { years } \\
2 \text { years } \\
3 \text { years } \\
1 \text { year } \\
7 \text { years } \\
5 \text { years } \\
6 \text { years } \\
3 \text { years } \\
4 \text { years } \\
3 \text { years } \\
6 \text { years } \\
8 \text { years } \\
7 \text { years } \\
2 \text { years }\end{array}$ & $\begin{array}{c}3 \text { months } \\
14 \text { days } \\
2 \text { months } \\
20 \text { days } \\
6 \text { weeks } \\
4 \text { weeks } \\
4 \text { months } \\
18 \text { months } \\
25 \text { days } \\
14 \text { days } \\
14 \text { days } \\
4 \text { months } \\
3 \text { weeks } \\
3 \text { weeks } \\
3 \text { weeks } \\
2 \text { weeks } \\
2 \text { weeks } \\
2 \text { weeks } \\
1 \text { day } \\
3 \text { months } \\
8 \text { months } \\
4 \text { months }\end{array}$ & $\begin{array}{c}\text { Complete } \\
\text { Complete } \\
\text { Complete } \\
\text { Partial } \\
\text { Complete } \\
\text { Partial } \\
\text { Partial } \\
\text { Partial } \\
\text { Complete } \\
\text { Partial } \\
\text { Slight } \\
\text { Slight } \\
\text { Slight } \\
\text { Slight } \\
\text { Complete } \\
\text { Partial } \\
\text { Slight } \\
\text { Slight } \\
\text { Slight } \\
\text { Complete } \\
\text { Slight } \\
\text { Complete }\end{array}$ & $\begin{array}{l}\text { None } \\
\text { None } \\
\text { None } \\
\text { None } \\
\text { None } \\
\text { None } \\
\text { None } \\
\text { None } \\
\text { None } \\
\text { None } \\
\text { None } \\
\text { None } \\
\text { None } \\
\text { None } \\
\text { None } \\
\text { None } \\
\text { None } \\
\text { None } \\
\text { None } \\
\text { None } \\
\text { None } \\
\text { None }\end{array}$ & $\begin{array}{c}\quad 0 \\
1-70 \\
1-60 \\
1-80 \\
1-40 \\
1-10 \\
1-50 \\
0 \\
1-150 \\
1-240 \\
1-120 \\
1-20 \\
1-60 \\
1-50 \\
1-60 \\
1-10 \\
1-30 \\
1-30 \\
0 \\
1-70 \\
0 \\
1-10\end{array}$ & $\begin{array}{r}0 \\
0 \\
1-20 \\
1-10 \\
0 \\
1-10 \\
1-10 \\
0 \\
1-30 \\
0 \\
1-30 \\
1-10 \\
0 \\
0 \\
1-10 \\
0 \\
0 \\
0 \\
0 \\
1-10 \\
0 \\
0\end{array}$ \\
\hline
\end{tabular}

Twenty-two persons with active pertussis or history of a recent attack were tested for complement-fixation. Serum was obtained at various times during the attack and also from persons who had had pertussis eighteen months before. All the cases of pertussis examined at about two weeks after the onset of the whoop gave complementfixation, fixation being not absolutely complete but very definite and distinct. At later periods the fixation became more marked. Six to eight weeks after the onset of the disease the complement-fixation was always complete. At three months or so after the onset of the 
attack, the fixation of the complement was still complete. At eight months the reaction was present but not as marked as at three months. One case which gave a history of severe pertussis eighteen months previously showed a slight fixation. Persons who had had pertussis two, three, and five years previously showed no fixation. Serum was obtained from one case at the very onset of the attack, but there was neither fixation at this time, nor nine days after onset. At eighteen days after the beginning of the whoop, there was a slight but distinct fixation.

When the influenza bacillus was used as antigen, all the sera that gave positive results with the bacillus pertussis, gave uniformly negative results.

\section{AGgLUTINATION}

The serum of rabbits injected with the bacillus of pertussis aggiutinated the organism in dilutions of $1-1,000$, but had no effect on the influenza bacillus. The serum of rabbits injected with the influenza bacillus agglutinated this organism in dilutions of $1-500$, but had no effect on the pertussis organism.

The serum of the patients with pertussis, or convalescing therefrom, showed variable agglutinating properties towards the bacillus of pertussis. Agglutination in dilution of 1-60 frequently occurred at two to three weeks after the onset of the disease. The lowest titer was 1-10 at two weeks after the onset and the highest 1-240, likewise two weeks after the onset. There was no agglutination in the serum of the patients having had pertussis eight months and eighteen months before. At the time of the onset, there was no agglutination by the serum.

About half of the cases showed a slight agglutination, 1-20, with respect to the influenza bacillus. The other half gave no agglutination with this bacillus.

\section{CONCLUSIONS}

My results indicate that complement-fixation in pertussis is obtainable about two weeks after the onset of the disease. The fixation is not as strong at this time as it is eight to ten weeks after the onset. At eight months after the beginning of the whoop, the reaction may still be present but not marked.

When the influenza bacillus is used as antigen with serum of pertussis patients, no complement-fixation occurs. 
The serum of patients with pertussis, or convalescing from pertussis, agglutinates the bacillus pertussis, but the concentration of the agglutinin varies greatly.

The influenza bacillus is not agglutinated by the serum of pertussis patients in dilutions above 1-20.

These results, as well as the results of the tests for complementfixation and agglutination with the serum of immunized rabbits, indicate no relationship between the bacillus of pertussis and the bacillus of influenza; the results with the serum of patients indicate that the bacillus pertussis has a specific relationship to whooping-cough, but that the influenza bacillus has not. 